\title{
Microsatellite loci development and population genetics in Neotropical fish Curimata mivartii (Characiformes: Curimatidae)
}

\author{
Ricardo M Landínez-García ${ }^{1}{ }^{\text {, Edna J. Marquez }}{ }^{\text {Corresp. } 1}$ \\ ${ }^{1}$ Facultad de Ciencias, Escuela de Biociencias, Universidad Nacional de Colombia - Sede Medellín, Medellín, Colombia \\ Corresponding Author: Edna J. Marquez \\ Email address: ejmarque@unal.edu.co
}

The Curimatidae family plays an ecological role in the recycling and distribution of nutrients and constitutes a major food source for several commercially important fishes. Curimata mivartii, a member of this family, is considered a short-distance migratory species ( $\leq 100 \mathrm{~km}$ ), categorized by the International Union for Conservation of Nature (IUCN) as a near threatened species, based on its declining population densities and habitat disturbance and fragmentation. Since population genetics and species-specific molecular tools remain unknown for all members of the Curimatidae family, this study developed a set of microsatellite loci and studied the population genetics of $C$. mivartii in the lower section of the Colombian Magdalena-Cauca basin. The results showed high levels of genetic diversity and evidence of gene flow even between locations separated over 350 $\mathrm{km}$. This information provides a baseline for designing conservation and management programs for C.mivartii and constitutes the first study of population genetics in Curimatidae. 
1 Microsatellite loci development and population genetics in Neotropical fish Curimata mivartii

2 (Characiformes: Curimatidae).

3

4

5 Ricardo M. Landínez-García and Edna J. Marquez

6

7 Universidad Nacional de Colombia-Sede Medellín-Facultad de Ciencias-Escuela de Biociencias.

8 Antioquia, Colombia.

9

10 Author correspondence: Edna. J. Marquez, Cra. 65 \#59A-110, Bloque 19 A Laboratorio 310 ,

11 Medellín, 050034 Colombia, ejmarque@unal.edu.co; ejmarque@gmail.com.

12

13

14 


\section{Abstract}

16 The Curimatidae family plays an ecological role in the recycling and distribution of nutrients and

17 constitutes a major food source for several commercially important fishes. Curimata mivartii, a

18 member of this family, is considered a short-distance migratory species $(\leq 100 \mathrm{~km})$, categorized

19 by the International Union for Conservation of Nature (IUCN) as a near threatened species,

20 based on its declining population densities and habitat disturbance and fragmentation. Since

21 population genetics and species-specific molecular tools remain unknown for all members of the

22 Curimatidae family, this study developed a set of microsatellite loci and studied the population

23 genetics of $C$. mivartii in the lower section of the Colombian Magdalena-Cauca basin. The

24 results showed high levels of genetic diversity and evidence of gene flow even between locations

25 separated over $350 \mathrm{~km}$. This information provides a baseline for designing conservation and

26 management programs for C.mivartii and constitutes the first study of population genetics in

27 Curimatidae. 

$512010)$.

\section{Introduction}

The Curimatidae (Pisces: Characiformes) family encompasses eight genera and approximately 105 species that present a wide distribution in the freshwater environments of the cis- and transAndean basins of South America (Melo et al., 2016a). This is the fourth most diverse family of the Characiformes order, and its members have been increasing in number over the last 20 years due to the discovery and introduction of new species (Melo et al., 2016a). Although their commercial importance is limited to the subsistence fisheries and ornamental species trade, these detritivorous, benthopelagic and migratory species contribute to the recycling and redistribution of nutrients (Alvarenga et al., 2006). Additionally, they represent higher percentages of biomass, providing food to birds and a large variety of fishes, particularly economically important catfish species, that support the nutritional safety of the riverside communities (Lasso et al., 2010).

Curimata mivartii Steindachner 1878, 'vizcaína' or 'cachaca' is a Colombian endemic species that represents the dominant biomass of the floodplain lakes in the middle basin of the Magdalena, San Jorge and Sinú rivers (Fig. 1). It is the largest Colombian trans-Andean species of the genus (approx. $35 \mathrm{~cm}$ ) and has a short-distance migration range (approx. $10.1 \mathrm{~km}$; average speed $0.3 \mathrm{~km} /$ day) (Lasso et al., 2010; López-Casas et al., 2016) through the main channel of the river. It forms great shoals and uses floodplain lakes as habitats for nourishment, refuge and larval development (Lasso et al., 2010). Like other species (Jiménez-Segura, Palacio \& Leite, 2010; Zapata \& Usma, 2013), its migrations seem to be related to changes in the water level of the rivers, which are bimodal in the Magdalena river basin (Jiménez-Segura, Palacio \& Leite, 
52 During migrations, C. mivartii is mainly exploited by subsistence fisheries, but it has become a

53

54

55

56

57

58

59

60

61

62

63

64

65

66

67

target of commercial fishing due to decreasing capture of traditional species (Mojica et al., 2012). The estimated decline of $30 \%$ of its population density and the noticeable fragmentation of its habitats caused by the growing anthropic intervention have led to the inclusion of $C$. mivartii in the "Near Threatened" list, according to the IUCN. Additionally, biological information about the species is scarce and the population genetics is unknown for all members of the Curimatidae family, which limits the design of appropriate conservation and management programs.

In contrast, population genetics studies have been performed on members of the phylogenetically related family, Prochilodontidae (Melo et al., 2016b; Vari, 1989), with which Curimatidae shares habitats and migratory, benthopelagic and detritivorous features. These studies reveal that Prochilodontidae exhibits populations formed by both nongeographical (Hatanaka, HenriqueSilva \& Galetti Jr., 2006; López-Macías et al., 2009; Melo et al., 2013; Orozco B \& Narváez B, 2014) and geographically structured stocks (Landínez-García \& Márquez, 2016).

Given the genetic structure of Prochilodontidae populations and the short-distance migration described for C. mivartii, we hypothesized that their populations are structured according to an isolation by distance model (Wright, 1943). To test this hypothesis, this study developed a set of primers for microsatellite loci amplification and evaluated the genetic diversity and structure of C. mivartii samples from different locations along the main stream and some floodplain lakes of the Magdalena-Cauca basin, encompassing differences in distance extending to over $350 \mathrm{~km}$ between the farthest locations. 
74

75

76

77

78

79

80

81

82

83

84

85

86

87

88

89

90

91

92

93

94

95

\section{Materials \& Methods}

This study analyzed a total of 209 muscle tissues of $C$. mivartii from the main stream of the rivers and floodplain lakes in the lower section of the Colombian Magdalena-Cauca basin. The study area includes floodplains of the Andean Magdalena-Cauca basin that present riverbeds with an upper width of $500 \mathrm{~m}$, low velocities, rock shards and fine sediments. This area comprises a group of floodplain lakes, which are the principal habitats of $C$. mivartii and differ in size, depth, levels of connection and anthropic intervention (farming and cattle breeding). Additionally, during the last decade (between 1997/1998 and 2009/2010) the Magdalena-Cauca basin has been exposed to the remote more extreme effects of atypical climate fluctuations such as the El Niño Southern Oscillation (ENSO) events (IDEAM, 2014), with 8 to 9 successive months (NOAA's Climate Prediction Center, 2015) of extreme floods (La Niña) and droughts (El Niño) in trans-Andean fluvial systems (Bookhagen \& Strecker, 2010).

All samples, preserved in 70\% ethanol, were provided by Integral S.A., through two scientific cooperation agreements (19 ${ }^{\text {th }}$ September 2013; Grant CT-2013-002443). Sampling collection was performed from 2011 to 2013 by Integral S. A., framed under an environmental permit from Ministerio de Ambiente, Vivienda y Desarrollo Territorial de Colombia \# 0155 on January 30, 2009 for Ituango hydropower construction. The first group of samples was collected from the

92 Cauca river (Fig. 2A), from three floodplain lakes (Grande, Las Culebras, Panela - Bolívar Department), from a site on the Caribona river (La Raya, San Jacinto del Cauca - Bolívar Department) and from another site on the Man river (Caucasia - Antioquia Department). The second group of samples was collected from the Magdalena river (Fig. 2B), from a floodplain 
96 lake (Chucurí, Puerto Parra - Santander Department) and from a site on the main channel of the

97 river (Puerto Berrío, Antioquia Department).

98 To develop species-specific microsatellite loci, the sequence reads from the genomic library of

99 one specimen of C. mivartii, previously pyrosequenced by 454 FLX technology (Landínez-

100 García, Alzate \& Márquez, 2016), were analyzed using PRINSEQ lite software to eliminate

101 sequences of less than $100 \mathrm{pb}$ in length, duplicated reads and low-quality regions. Then,

102 PAL_FINDER v.0.02.03 (Castoe et al., 2010) was used to extract the reads that contained perfect

103 tri-, tetra- and pentanucleotide microsatellite motifs, Primer3 v.2.0 (Rozen \& Skaletsky, 2000)

104 for the primer designs in the flanking sequences of the microsatellite loci and ePCR

105 (Rotmistrovsky, Jang \& Schuler, 2004) for assessing the correct alignment of the primers. The

106 level of polymorphism was evaluated in 40 microsatellite loci and further genetic analyses were

107 performed with a set of loci that satisfied the characteristics required to validate new

108 microsatellite primers (Neff, Garner \& Pitcher, 2011; Fernandez-Silva et al., 2013; Schoebel et

109 al., 2013).

110 For genotyping, the PCR mixtures were performed in volumes of $10 \mu$ containing the following

111 final concentrations: 0.6 pmoles/ $\mu 1$ of each forward primer tagged on the 5 'end with one of the

112 adapters described by Blacket et al. (2012), 12 pmoles/ $\mu$ l of each reverse primer, $10 \mathrm{pmoles} / \mu \mathrm{l}$ of

113 each fluorescently labeled adapter, 1.1X Master Mix, 2.5\% v/v GC Enhancer Platinum Multiplex

114 PCR Master Mix (Applied Biosystems) and 3-5 $\mu \mathrm{g} / \mu \mathrm{l}$ of template DNA isolated with GeneJET

115 DNA purification kit (Thermo Scientific), following the manufacturer's instructions. The

116 amplification reactions were performed on a thermocycler T100 (BioRad) with an initial

117 denaturation step of $95^{\circ} \mathrm{C}$ for $3 \mathrm{~min}$, followed by 42 cycles consisting of a denaturation step of

$11890{ }^{\circ} \mathrm{C}$ for $22 \mathrm{~s}$, an annealing step of $56^{\circ} \mathrm{C}$ for $20 \mathrm{~s}$ and without an extension step or final 
119 elongation. The amplicons were separated by electrophoresis on an ABI 3730 XL automated 120 sequencer (Applied Biosystems) using LIZ500 (Applied Biosystems) as the internal molecular

121 size. Then, GeneMapper v.4.0 (Applied Biosystems) was used to denote and score the allelic

122 fragments according to their molecular size and Micro-Checker v.2.2.3 (van Oosterhout et al., 123 2004) was run to detect potential genotyping errors.

124 The average number of alleles per locus and the polymorphism information content (PIC) for 125 each marker were calculated respectively using GenAlEx v.6.503 (Peakall \& Smouse, 2006) and

126 Cervus v.3.0.7 (Marshall et al., 1998). The average number of alleles per locus, observed and 127 expected average heterozygosities and fixation index were calculated to estimate the genetic diversity of C. mivartii. Tests for departures from Hardy-Weinberg and linkage equilibria as

129 well as the observed $\left(\mathrm{H}_{\mathrm{O}}\right)$ and expected $\left(\mathrm{H}_{\mathrm{E}}\right)$ heterozygosities were estimated using Arlequin v.3.5.2.2 (Excoffier, Laval \& Schneider, 2005). The sequential Bonferroni correction was applied to adjust the statistical significance in multiple comparisons (Rice, 1989).

To explore nonneutral evolutive forces acting on the microsatellite loci, scanning analyses were performed using BayeScan v.2.1 (Foll \& Gaggiotti, 2008) software to detect diversifying, positive or balancing selection. Parameters included 10:1 prior odds for the neutral model, 20 pilot runs consisting of 5,000 iterations each, followed by 200,000 iterations and a burn-in of 50,000 iterations. The loci were ranked according to their estimated posterior probability or 137 posterior odds (equivalent to the Bayes factor), a statistical criterion to test the model. Positive 138 alpha values were then used to distinguish microsatellites under diversifying selection, while 139 negative alpha values were used to detect balancing selection (Foll \& Gaggiotti, 2008).

140 To explore whether outlier loci found in this study represented false positives, the ocurrence of 141 recent genetic bottlenecks of populations was evaluated by calculating the levels of 
142 heterozygosity using the Wilcoxon sign-rank test (Luikart \& Cornuet, 1998) included in

143 Bottleneck v.1.2.02 software (Piry, Luikart \& Cornuet, 1999). Addittionally, the M ratio (the

144 mean ratio of the number of alleles compared with the range in allele size) was calculated using

145 Arlequin v.3.5.2.2 (Excoffier, Laval \& Schneider, 2005). The M ratio indicates that the

146 population has experienced recent and severe reduction in population size when its values are

147 smaller than 0.68 (Garza \& Williamson, 2001).

148 After exploring the genetic structure of the samples, the hypothesis of isolation by distance was

149 tested using a Mantel test (Mantel, 1967) implemented in GenAlex v.6.503 (Peakall \& Smouse,

150 2006). The genetic structure among geographical samples was calculated using the standardized

151 statistics F' ${ }^{\prime}$ ST (Meirmans, 2006) and Jost's D est (Meirmans \& Hedrick, 2011), analysis of

152 molecular variance (AMOVA) (Meirmans, 2006), with 10,000 permutations and bootstraps

153 included in GenAlex v.6.503 (Peakall \& Smouse, 2006). Patterns of genetic structure were

154 further explored, using the diploid genotypes of 20 loci (40 variables) in 209 individuals, which

155 were submitted to discriminant analysis of principal components using the R package Adegenet

156 (Jombart, 2008).

157 Likewise, Bayesian analysis of population partitioning implemented in STRUCTURE v.2.3.4

158 (Pritchard, Stephens \& Donnelly, 2000) was used to examine other sample groupings.

159 Parameters included 350,000 Monte Carlo Markov Chain steps and 20,000 iterations such as 160 burn-in, admixture model, correlated frequencies and the LOCPRIOR option for detecting 161 relatively weak population structures (Hubisz et al., 2009). Each analysis was repeated 20 times 162 for each simulated $\mathrm{K}$ value, which ranged from 1 to 10 groups. For the best estimation of genetic 163 stocks $(\mathrm{K})$, the $\Delta \mathrm{K}$ ad hoc statistic (Evanno, Regnaut \& Goudet, 2005) was calculated using 164 STRUCTURE HARVESTER (Earl \& VonHoldt, 2012). Then, CLUMPP v.1.1.2b (full-search 
165 algorithm, function G'normalized, parameters at their default values) (Jakobsson \& Rosenberg,

166 2007) and DISTRUCT v.1.1 (Rosenberg, 2004) were used, respectively, to summarize the results

167 of independent STRUCTURE runs and plot the Q-matrix obtained in a histogram, displaying the

168 ancestry of each individual in each population.

169

170 Results

171

172 A set of 27 out of the 40 loci evaluated was selected as they showed clearly defined peaks, the

173 absence of stutter bands, nonspecific bands, high polymorphism, reproducibility and correct

174 motif sizes, among other parameters proposed (Neff, Garner \& Pitcher, 2011; Fernandez-Silva et

175 al., 2013; Schoebel et al., 2013). These microsatellite loci include penta- (4), tetra- (8) and

176 trinucleotide (15) motifs, which exhibited allele lengths ranging from 90 to $350 \mathrm{bp}$ and PIC

177 values ranging from 0.549 to 0.946 (average: 0.791 ) (Table 1). The number of alleles per locus

178 ranged from 6 to 23 (average: 10.493) and the average levels of heterozygosity across loci and

179 samples were $\mathrm{Ho}=0.757$ and $\mathrm{He}=0.801$ (Table 2$)$. These genetic diversity parameters showed

180 the highest values in the floodplain lake Las Culebras (10.900 alleles per locus; Ho $=0.757 ; \mathrm{He}$

$181=0.793)$ and the lowest values in La Raya (9.650 alleles per locus; $\mathrm{Ho}=0.734 ; \mathrm{He}=0.803$ )

182 (Table 2).

183 The pairwise tests of genotypic disequilibrium were nonsignificant and no evidence of null

184 alleles or scoring errors were detected by Micro-Checker in the overall sample. However, five of 185 the 27 loci (Cmi02, Cmi05, Cmi07, Cmi34 andCmi48) showed the lowest PIC values (Table 1),

186 departure of allelic frequencies from Hardy-Weinberg equilibrium expectations in three or more

187 of the evaluated samples and inconsistencies in the amplification (Table 2); consequently, they 
188 were excluded from additional analysis. Furthermore, the BayeScan analyses showed significant 189 evidence of putative signals of diversyifing/positive selection for the additional loci Cmi35 190 (posterior probability: 0.946; $\log _{10} \mathrm{PO}: 1.242$; alpha: 1.339 and $\mathrm{P}_{\text {Simul Fst }<\text { sample Fst }}$ 0.032) and 191 Cmi42 (posterior probability: 0.999; $\log _{10} \mathrm{PO}: 3.699$; alpha: 1.670 and $\mathrm{P}_{\text {Simul Fst < sample Fst }}$ 0.042) 192 in the comparison between the floodplain lake Las Culebras and the remaining localities.

193 Results from the Bottleneck tests (Table 3) were significant for all populations under the infinite 194 alleles model (IAM) and some populations under the two-phase model (TPM); whereas they were non-significant under the stepwise mutation model (SMM). Due to the thought that few loci follow the strict SMM (Piry, Luikart \& Cornuet, 1999), the best estimation of expected heterozygosity at mutation-drift equilibrium is expected under a combination of IAM and TPM. Additionally, all values of the $\mathrm{M}$ ratio were substancially smaller than 0.68 , indicating that all populations have experienced recent and severe reduction in population size (Table 3).

200

201

202

203

204

205

206

207

208 209

The Bayesian analysis, DPCA (Fig. 3A and B), AMOVA $\left(\mathrm{F}^{\prime}{ }_{\mathrm{ST}}=0.001 ; \mathrm{P}=0.285\right)$ and pairwise comparisons with standardized estimators $\mathrm{F}_{\text {ST }}$ and Jost's Dest (Table 4), evidenced the presence of a single genetic stock. Consequently, the Mantel test showed a weak spatial correlation of genetic distances in the evaluated sector $\left(\mathrm{R}^{2}=0.001 ; \mathrm{P}=0.031\right)$.

\section{Discussion}

This study tested the hypothesis that C. mivartii exhibits genetically structured populations, according to an isolation by distance model; to accomplish that, a set of primers was developed 
210 for the amplification of 27 loci microsatellites, 22 of which exhibited allelic frequencies

211 according to Hardy-Weinberg equilibrium expectations in most of the evaluated samples. This

212 work also showed evidence of putative selection in $9.091 \%$ of the 22 loci examined, which is in

213 line with the percentage of outlier loci (5-18\%) reported for microsatellites in migratory marine

214 fishes (Larsson et al., 2007; Rhode et al., 2013; Liu et al., 2016) and different molecular markers

215 in other taxa [for reviews see (Nosil, Funk \& Ortiz-Barrientos, 2009)].

216 The outlier loci found in this study may represent false positives resulting from the inclusion of

217 severely bottlenecked populations (Teshima, Coop \& Przeworski, 2006; Foll \& Gaggiotti, 2008),

218 although the significant excess of heterozygosity and small $\mathrm{M}$ ratio values were found even in

219 populations that did not exhibit outlier loci. Alternatively, the outlier loci may result from

220 asymmetryc gene flow by unidirectional migration (Hansen, Meier \& Mensberg, 2010) as well

221 as hitchhiking selection resulting from temporal disconnections between the floodplain lake Las

222 Culebras and the Caribona river main stream. Although the contribution of these events in the

223 observed findings remains unaddressed, both explanations are plausible considering the

224 positive/negative ENSO successions observed in the last decade for the Magdalena-Cauca basin,

225 the strongest recorded so far for this basin in terms of low water levels and high temperatures

226 (IDEAM, 2014).

227 As this is the first report of population genetics for a species of the Curimatidae family, the

228 results of this study were compared with species of the phylogenetically related family,

229 Prochilodontidae. In C. mivartii values of the average number of alleles per locus (10.493) and

230 expected and observed heterozygosities $(\mathrm{Ho}=0.757$ and $\mathrm{He}=0.801)$ were similar to those found

231 in studies that used species-specific microsatellite loci with large repeat motifs such as $P$. 
232 argenteus (Sanches et al., 2012; Melo et al., 2013) and Ichthyoelephas longirostris (Landínez-

233 García \& Márquez, 2016).

234 In contrast to the a priori expectation of a population structure concordant with an isolation by

235 distance model, this study evidenced a high genetic connectivity of $C$. mivartii even in localities

236 separated by over $350 \mathrm{~km}$ (Man river and Puerto Berrío). Given that this species is considered a

237 short-distance migrant ( $<100 \mathrm{~km}$; Zapata \& Usma, 2013), a decrease in genetic similarity is

238 expected among populations as the geographic distance between them increases. However, allele

239 frequencies found in this study were not spatially autocorrelated at distances two and three times

240 longer than the estimated migration range of $C$. mivartii, providing no support to our hypothesis.

241 The above findings may indicate that the dispersion range of the species is underestimated as the

242 only register $(10.1 \mathrm{~km})$ published contained information about the recapture of a single

243 individual out of 149 marked, using the mark-recapture method (López-Casas et al., 2016).

244 Consequently, this outcome suggests that C. mivartii exhibits at least a medium migration range,

245 a category that includes a displacement capacity of between 100 and $500 \mathrm{~km}$ (Zapata \& Usma,

246 2013).

247 An alternative and non-excluding explanation is that C. mivartii displacements are performed in

248 various events and in different directions and magnitudes, thereby providing a possible

249 explanation for the high levels of connection among floodplain lakes along the studied range.

250 This may also imply that $C$. mivartii does not exhibit a homing behavior like that described in

251 various members of the Prochilodontidae family (Godinho \& Kynard, 2006).

252 Similarly, given the sample collection period, the extensive gene flow might have resulted from a

253 strong 2010/2011 La Niña event, which affected precipitation patterns world-wide (Boening et

254 al., 2012) and caused damage in Colombia associated with ocurrences of floods, windstorms, 
255 lightning and landslides (Hoyos et al., 2013). This event, preceded by warm anomalies during the

256 first quarter of 2010 (Hoyos et al., 2013), may also explain an apparent excess of novel alleles

257 and an incomplete allele frequency distribution, as evidenced by the Bottleneck analysis.

258 In summary, rejecting the hypothesis of isolation by distance, C. mivartii represents a single

259 stock in the lower section of the Colombian Magdalena-Cauca basin, which exhibits high genetic

260 diversity and an apparent recent and severe reduction in population size. This information

261 constitutes a baseline for monitoring the population genetics of these species that inhabit main

262 streams of the rivers and floodplain lakes downstream from the Ituango hydropower

263 construction. Additionally, this knowledge is crucial to establish conservation units and

264 facilitiate its management.

266 Conclusions

268 The results of this study indicate that populations of $C$. mivartii are not structured according to an isolation by distance model in a sector three times longer than its estimated migration range

$270(<100 \mathrm{~km})$. This study also developed a group of 20 loci microsatellites, the first report for the

271 Curimatidae family, that can be used in subsequent studies to delve into the conservation, basic

272 genetics and biology of the species. Additionally, we found two outlier loci putatively under

273 selection that will require further assesment in estimating their usefulness in future studies. These

274 markers may be valuable for delineating conservation units known as Management, Adaptive

275 and Evolutionarily Significant Units (Funk et al., 2012), thereby providing a more complete

276 insight into the evolutionary potential for conservation of wild populations and the short- and 
277 long-term persistence of the species in the Magdalena-Cauca basin, a historically neglected

278 aspect among most Neotropical fish species.

\section{Acknowledgements}

282

283

The authors would like to thank the Centro Nacional de Enunciation Genómica, Universidad de

Antioquia (Medellín, Colombia), for their assistance with bioinformatics analysis and José

Gregorio Martínez for his collaboration in the analysis of the putative signal of

286

diversifying/positive selection loci. The authors also thank to Cesar Amaral and the anonymous

reviewers for their comments that improved the final version of this article.

\section{References}

290

291

292

293

294

295

296

297

298

299

Alvarenga ÉR., Bazzoli N., Santos GB., Rizzo E. 2006. Reproductive biology and feeding of Curimatella lepidura (Eigenmann \& Eigenmann) (Pisces, Curimatidae) in Juramento reservoir, Minas Gerais, Brazil. Revista Brasileira de Zoología 23:314-322. DOI: 10.1590/S0101-81752006000200002.

Blacket MJ., Robin C., Good RT., Lee SF., Miller AD. 2012. Universal primers for fluorescent labelling of PCR fragments-an efficient and cost-effective approach to genotyping by fluorescence. Molecular Ecology Resources 12:456-463. DOI: 10.1111/j.17550998.2011.03104.x.

Boening C., Willis JK., Landerer FW., Nerem RS., Fasullo J. 2012. The 2011 la Nia: So strong, the oceans fell. Geophysical Research Letters 39:1-5. DOI: 10.1029/2012GL053055.

Bookhagen B., Strecker MR. 2010. Modern Andean rainfall variation during ENSO cycles and its impact on the Amazon drainage basin. In: Hoorn C, Wesselingh FP eds. Amazonia, Landscape and Species Evolution: A Look into the Past. Amsterdam, The Netherlands: Blackwell Publishing, 482. 
Castoe TA., Poole AW., Gu W., Jason de Koning AP., Daza JM., Smith EN., Pollock DD. 2010. Rapid identification of thousands of copperhead snake Agkistrodon contortrix microsatellite loci from modest amounts of 454 shotgun genome sequence. Molecular Ecology Resources 10:341-347. DOI: $10.1111 /$ j.1755-0998.2009.02750.x.

Earl DA., VonHoldt BM. 2012. STRUCTURE HARVESTER: A website and program for visualizing STRUCTURE output and implementing the Evanno method. Conservation Genetics Resources 4:359-361. DOI: 10.1007/s12686-011-9548-7.

Evanno G., Regnaut S., Goudet J. 2005. Detecting the number of clusters of individuals using the software structure: A simulation study. Molecular Ecology 14:2611-2620. DOI: 10.1111/j.1365-294X.2005.02553.x.

Excoffier L., Laval G., Schneider S. 2005. Arlequin (version 3.0): An integrated software package for population genetics data analysis. Evolutionary Bioinformatics 1:47-50. DOI: 10.4137/EBO.S0.

Fernandez-Silva I., Whitney J., Wainwright B., Andrews KR., Ylitalo-Ward H., Bowen BW., Toonen RJ., Goetze E., Karl SA. 2013. Microsatellites for next-generation ecologists: A post-sequencing bioinformatics pipeline. PLoS One 8:e55990. DOI: 10.1371/journal.pone.0055990.

Foll M., Gaggiotti O. 2008. A genome-scan method to identify selected loci appropriate for both dominant and codominant markers: A Bayesian perspective. Genetics 180:977 LP-993. DOI: $10.1534 /$ genetics. 108.092221 .

Funk W., McKay J., Hohenlohe P., Allendorf F. 2012. Harnessing genomics for delineating conservation units. Trends in Ecology and Evolution 27:489-496. DOI: 10.1016/j.tree.2012.05.012.

Garza JC., Williamson EG. 2001. Detection of reduction in population size using data from microsatellite loci. Molecular Ecology 10:305-318. DOI: 10.1046/j.1365294X.2001.01190.x..

Godinho AL., Kynard B. 2006. Migration and spawning of radio-tagged zulega Prochilodus argenteus in a dammed brazilian river. Transactions of the American Fisheries Society 135:811-824. DOI: 10.1577/T04-176.1.

Hansen MM., Meier K., Mensberg K. 2010. Identifying footprints of selection in stocked brown trout populations: a spatio-temporal approach. Molecular Ecology 19:1787-1800. DOI: 10.1111/j.1365-294X.2010.04615.x.

Hatanaka T., Henrique-Silva F., Galetti Jr. PM. 2006. Population substructuring in a migratory freshwater fish Prochilodus argenteus (Characiformes, Prochilodontidae) from the São Francisco River. Genetica 126:153-159. DOI: 10.1007/s10709-005-1445-0.

Hoyos N., Escobar J., Restrepo JC., Arango AM., Ortiz JC. 2013. Impact of the 2010-2011 La Niña phenomenon in Colombia, South America: The human toll of an extreme weather event. Applied Geography 39:16-25. DOI: 10.1016/j.apgeog.2012.11.018. 
Hubisz MJ., Falush D., Stephens M., Pritchard JK. 2009. Inferring weak population structure with the assistance of sample group information. Molecular Ecology Resources 9:13221332. DOI: $10.1111 / \mathrm{j} .1755-0998.2009 .02591 . x$.

IDEAM - Instituto de Hidrología Meteorología y Estudios Ambientales. 2014.Fenómeno El Niño y La Niña - FENÓMENOS EL NIÑO Y LA NIÑA - IDEAM. DOI: http://www.ideam.gov.co/web/pronosticos-y-alertas/pronosticos-alertas/fenomenos-el-ninoy-la-nina/.

Jakobsson M., Rosenberg NA. 2007. CLUMPP: A cluster matching and permutation program for dealing with label switching and multimodality in analysis of population structure. Bioinformatics 23:1801-1806. DOI: 10.1093/bioinformatics/btm233.

Jiménez-Segura LF., Palacio J., Leite R. 2010. River flooding and reproduction of migratory fish species in the Magdalena River basin, Colombia. Ecology of Freshwater Fish 19:178-186. DOI: $10.1111 / \mathrm{j} .1600-0633.2009 .00402 . x$.

Jombart T. 2008. ADEGENET: A R package for the multivariate analysis of genetic markers. Bioinformatics 24:1403-1405. DOI: 10.1093/bioinformatics/btn129.

Landínez-García RM., Alzate JF., Márquez EJ. 2016. Mitochondrial genome of the neotropical detritivore fish Curimata mivartii Steindachner 1878 (Characiformes, Curimatidae). Mitochondrial DNA Part A 27:2196-2197. DOI: 10.3109/19401736.2014.982623.

Landínez-García RM., Márquez EJ. 2016. Development and characterization of 24 polymorphic microsatellite loci for the freshwater fish Ichthyoelephas longirostris (Characiformes: Prochilodontidae). PeerJ 4:e2419. DOI: 10.7717/peerj.2419.

Larsson LC., Laikre L., Palm S., Andre C., Carvalho GR., Ryman N. 2007. Concordance of allozyme and microsatellite differentiation in a marine fish, but evidence of selection at a microsatellite locus. Molecular Ecology 16:1135-1147. DOI: 10.1111/j.1365294X.2006.03217.x.

Lasso C., Agudelo E., Jimenez-Segura L., Ramírez-Gil H., Morales-Betancourt M., AjiacoMartínez R., Gutiérres F de la P., Usma S., Muñoz S., Sanabria-Ochoa A. 2010. Catálogo de los recursos pesqueros continentales de Colombia. Bogotá, D. C., Colombia: Instituto de Investigación de Recursos Biológicos Alexander von Humboldt (IAvH).

Liu B-J., Zhang B-D., Xue D-X., Gao T-X., Liu J-X. 2016. Population structure and adaptive divergence in a high gene flow marine fish: The small yellow croaker (Larimichthys polyactis). PloS One 11:e0154020. DOI: 10.1371/journal.pone.0154020.

López-Casas S., Jiménez-Segura LF., Agostinho AA., Pérez CM. 2016. Potamodromous migrations in the Magdalena River basin: Bimodal reproductive patterns in neotropical rivers. Journal of Fish Biology 89:157-171. DOI: 10.1111/jfb.12941.

López-Macías JN., García Vallejo F., Rubio E., Rincón E., Castillo Giraldo A., Cerón F., LópezMacias JN., Garcia Vallejo F., Rúbio Rincón E., Castillo Giraldo A., Cerón F. 2009. Diversidad Genética del Bocachico (Prochilodus reticulatus) de la Cuenca Alta del Río 
407

408

409

410

411

412

413 414

415 416

Cauca (Colombia). Acta Biológica Paranaense 38:113-138. DOI: 10.5380/abpr.v38i0.16928.

Luikart G., Cornuet JM. 1998. Empirical evaluation of a test for identifying recently bottlenecked populations from allele frequency data. Conservation Biology 12:228- 237.

Mantel N. 1967. The detection of disease clustering and a generalized regression approach. Cancer Research 27:209-220.

Marshall TC., Slate J., Kruuk LE., Pemberton JM. 1998. Statistical confidence for likelihoodbased paternity inference in natural populations. Molecular Ecology 7:639-655. DOI: 10.1046/j.1365-294x.1998.00374.x.

Meirmans PG. 2006. Using the AMOVA framework to estimate a standardized genetic differentiation measure. Evolution 60:2399-2402. DOI: 10.1111/j.00143820.2006.tb01874.x.

Meirmans PG., Hedrick PW. 2011. Assessing population structure: Fst and related measures. Molecular Ecology Resources 11:5-18. DOI: 10.1111/j.1755-0998.2010.02927.x.

Melo BF., Ochoa LE., Vari RP., Oliveira C. 2016a. Cryptic species in the Neotropical fish genus Curimatopsis (Teleostei, Characiformes). Zoologica Scripta 45:650-658. DOI: 10.1111/zsc.12178.

Melo BF., Sato Y., Foresti F., Oliveira C. 2013. The roles of marginal lagoons in the maintenance of genetic diversity in the Brazilian migratory fishes Prochilodus argenteus and P. costatus. Neotropical Ichthyology 11:625-636. DOI: 10.1590/S167962252013000300016.

Melo BF., Sidlauskas BL., Hoekzema K., Frable BW., Vari RP., Oliveira C. 2016b. Molecular phylogenetics of the Neotropical fish family Prochilodontidae (Teleostei: Characiformes). Molecular Phylogenetics and Evolution 102:189-201. DOI: 10.1016/j.ympev.2016.05.037.

Mojica JI., Usma JS., Álvarez-León R., Lasso CA. 2012. Libro rojo de peces dulceacuícolas de Colombia. Bogotá, D. C.: Instituto de Investigación de Recursos Biológicos Alexander von Humboldt, Instituto de Ciencias Naturales de la Universidad Nacional de Colombia, WWF Colombia y Universidad de Manizales.

Neff BD., Garner SR., Pitcher TE. 2011. Conservation and enhancement of wild fish populations: preserving genetic quality versus genetic diversity. Canadian Journal of Fisheries and Aquatic Sciences 68:1139-1154. DOI: 10.1139/f2011-029.

NOAA's Climate Prediction Center. 2015.Historical El Nino / La Nina episodes (1950-present)

Nosil P., Funk DJ., Ortiz-Barrientos D. 2009. Divergent selection and heterogeneous genomic divergence. Molecular Ecology 18:375-402. DOI: 10.1111/j.1365-294X.2008.03946.x.

van Oosterhout C., Hutchinson WF., Wills DPM., Shipley P. 2004. Micro-Checker: Software for identifying and correcting genotyping errors in microsatellite data. Molecular Ecology 
Notes 4:535-538. DOI: 10.1111/j.1471-8286.2004.00684.x.

418

419

420

421

422

423

424

425

426

427

428

429

430

431

432

433

434

435

436

437

438

439

440

441

442

443

444

445

446

447

448

449

450

451

452

453

Orozco B G., Narváez B JC. 2014. Genetic diversity and population structure of bocachico Prochilodus magdalenae (Pisces, Prochilodontidae) in the Magdalena River basin and its tributaries, Colombia. Genetics and Molecular Biology 37:37-45.

Peakall R., Smouse PE. 2006. Genalex 6: Genetic analysis in Excel, population genetic software for teaching and research. Molecular Ecology Notes 6:288-295. DOI: 10.1111/j.14718286.2005.01155.x.

Piry S., Luikart G., Cornuet J. M. 1999. BOTTLENECK: A computer program for detecting recent reductions in the effective population size using allele frequency data. Heredity 90:502-503. DOI: 10.1093/jhered/90.4.502.

Pritchard JK., Stephens M., Donnelly P. 2000. Inference of population structure using multilocus genotype data. Genetics 155:945-959.

Rhode C., Vervalle J., Bester-van der Merwe AE., Roodt-Wilding R. 2013. Marine genomics detection of molecular signatures of selection at microsatellite loci in the south african abalone ( Haliotis midae ) using a population genomic approach. Marine Genomics 10:2736. DOI: 10.1016/j.margen.2013.03.001.

Rice WR. 1989. Analyzing tables of statistical tests. Evolution 43:223-225.

Rosenberg NA. 2004. Distruct: a program for the graphical display of population structure. Molecular Ecology Notes 4:137-138. DOI: 10.1046/j.1471-8286.2003.00566.x.

Rotmistrovsky K., Jang W., Schuler GD. 2004. A web server for performing electronic PCR. Nucleic Acids Research 32:108-112. DOI: 10.1093/nar/gkh450.

Rozen S., Skaletsky H. 2000. Primer3 on the World Wide Web for general users and for biologist programmers. In: Krawetz S, Misener S eds. Bioinformatics Methods and Protocols: Methods in Molecular Biology. New Jersey: Humana Press, 365-386.

Sanches A., Galetti Jr. PM., Galzerani F., Derazo J., Cutilak Bianchi B., Hatanaka T. 2012. Genetic population structure of two migratory freshwater fish species (Brycon orthotaenia and Prochilodus argenteus) from the Sao Francisco River in Brazil and its significance for conservation. Latin American Journal of Aquatic Research 40:177-186. DOI: 10.3856/vol40-issue1-fulltext-17.

Schoebel CN., Brodbeck S., Buehler D., Cornejo C., Gajurel J., Hartikainen H., Keller D., Leys M., Ríčanová S., Segelbacher G., Werth S., Csencsics D. 2013. Lessons learned from microsatellite development for nonmodel organisms using 454 pyrosequencing. Journal of Evolutionary Biology 26:600-611. DOI: 10.1111/jeb.12077.

Teshima KM., Coop G., Przeworski M. 2006. How reliable are empirical genomic scans for selective sweeps? Genome Research 16:702-712. DOI: 10.1101/gr.5105206.

Vari RP. 1989. A phylogenetic study of the neotropical characiform family Curimatidae (Pisces: Ostariophysi). Smithsonian Contributions to Zoology 471:1-71. 
454 Wright S. 1943. Isolation by distance. Genetics 28:114-138.

455 Zapata LA., Usma JS. 2013. Guía de las especies migratorias de la biodiversidad en Colombia. 456 Peces. Bogota, D.C.; Colombia: Ministerio de Ambiente y Desarrollo Sostenible / WWF457 Colombia. 


\section{Figure 1}

Photography of Curimata mivartii, a freshwater fish endemic to Colombia

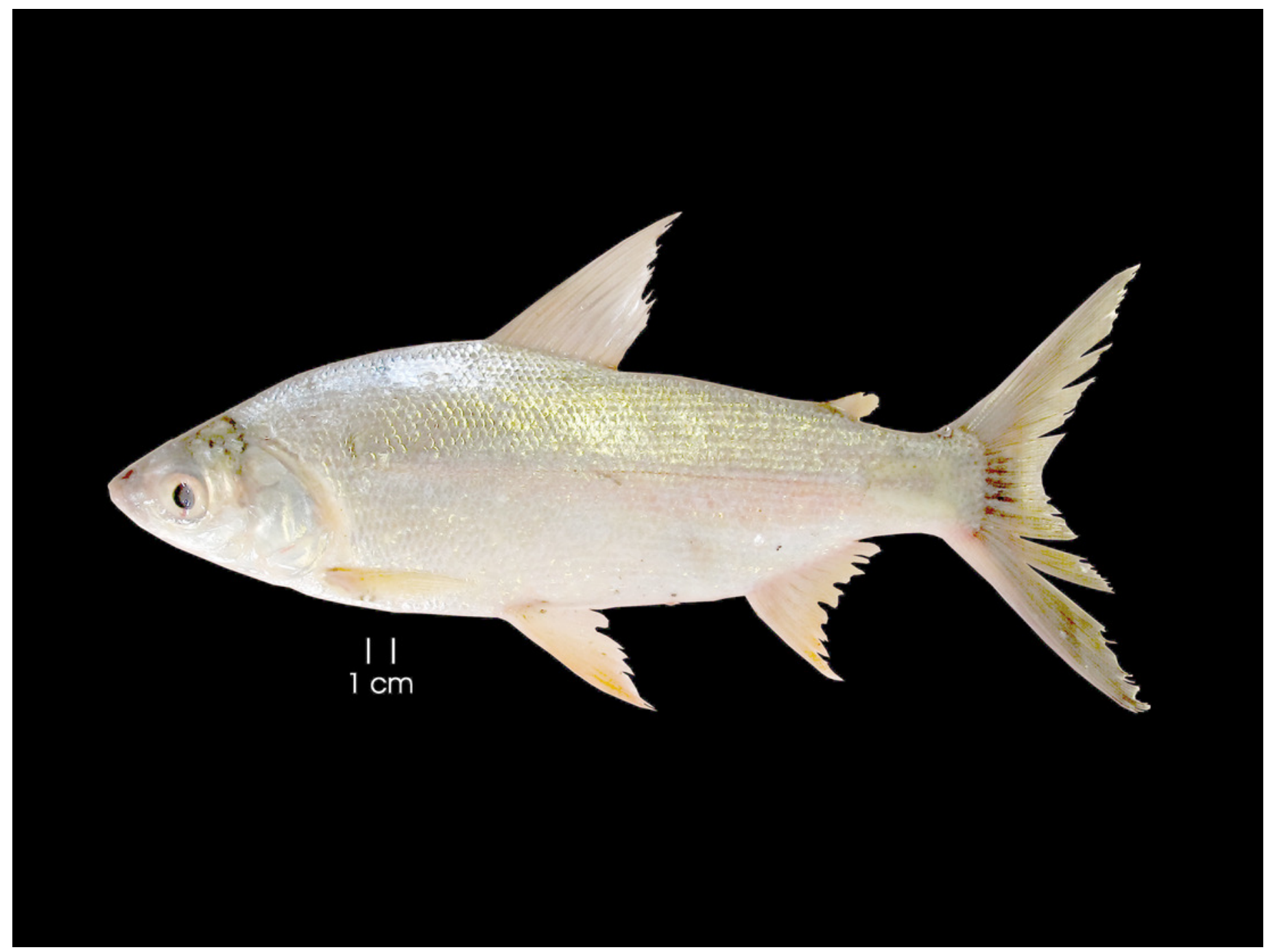


Figure 2

Sampling sites (star) of Curimata mivartii in some sectors of the Colombian rivers Cauca (A) and Magdalena (B)
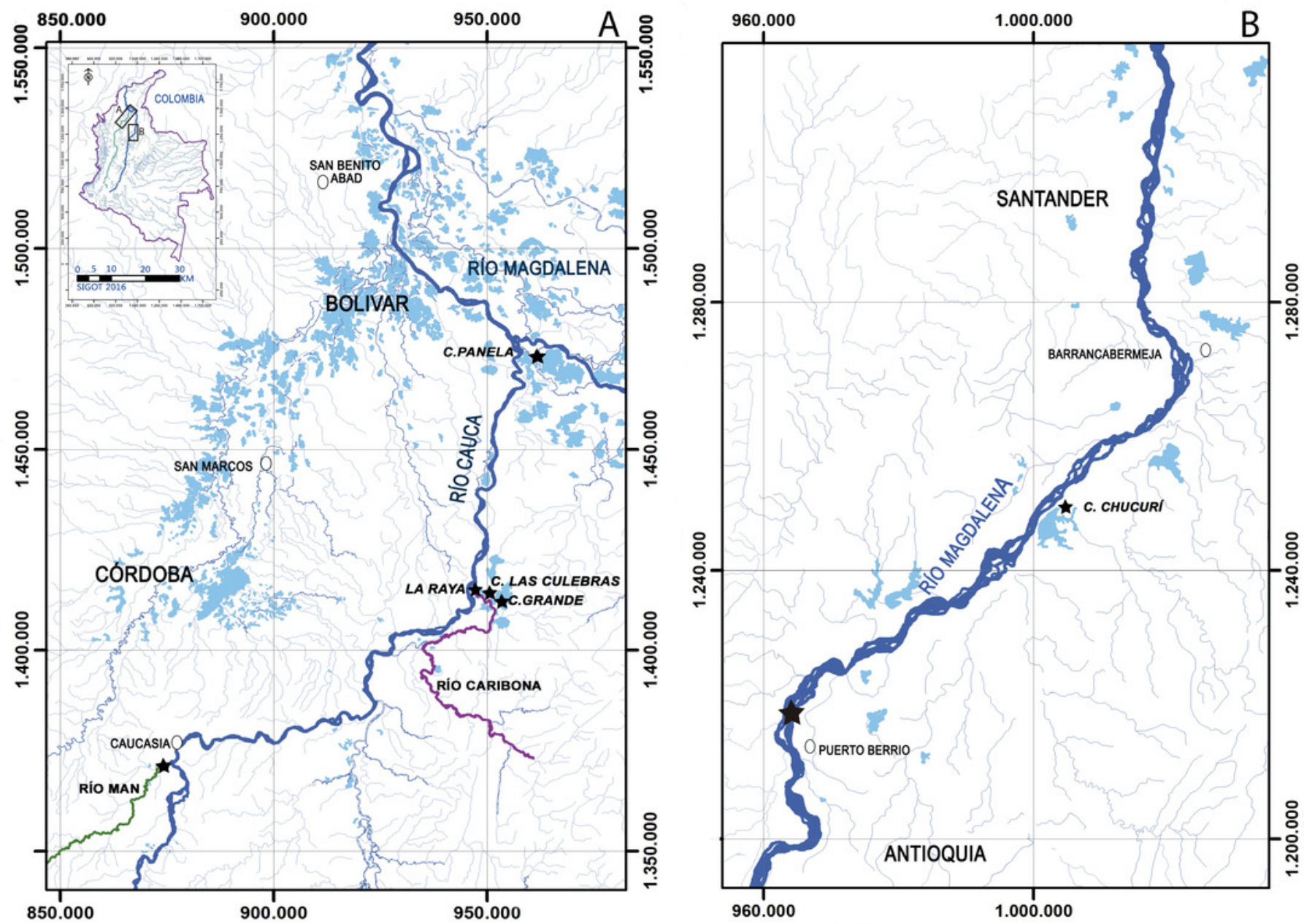
Figure 3

Population structure suggested by STRUCTURE $(A)$ and discriminant analysis of principal components (B)

Bar plot of population ancestry coefficients estimated by STRUCTURE is provided for $K=2$ and Q-matrixes were consensus estimates produced by CLUMPP across 20 iterations of STRUCTURE.

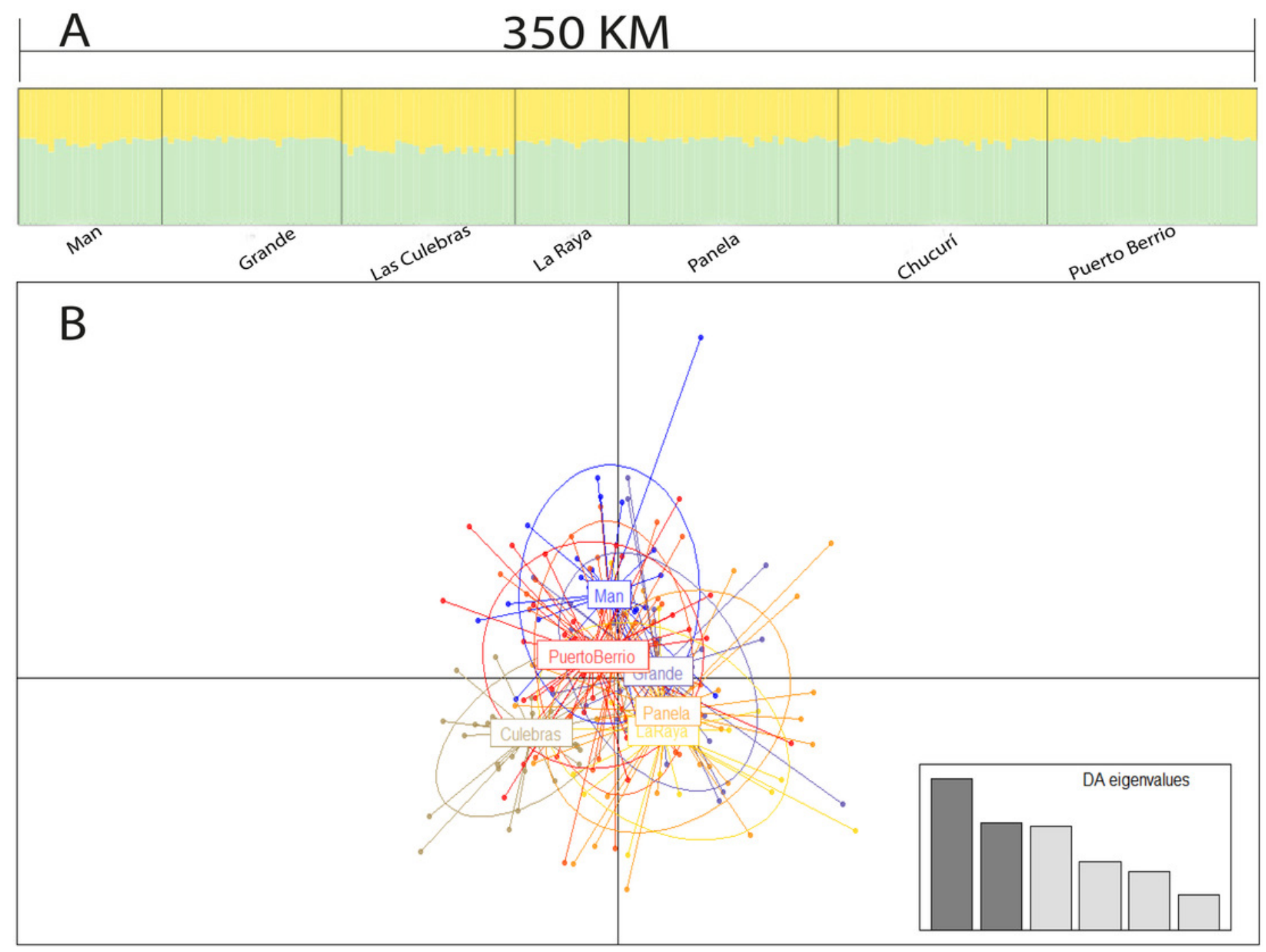




\section{Table $\mathbf{1}$ (on next page)}

Primer sequences and characteristics of 27 microsatellite loci selected for Curimata mivartii 


\begin{tabular}{|c|c|c|c|c|}
\hline $\begin{array}{l}\text { Locus } \\
\text { Name }\end{array}$ & $\begin{array}{l}\text { Primer sequence for forward (F)and reverse (R) } \\
\qquad\left(5^{\prime}-3^{\prime}\right)\end{array}$ & $\begin{array}{c}\text { Repeat } \\
\text { motif }\end{array}$ & $\begin{array}{l}\text { Size range } \\
\text { (bp) }\end{array}$ & PIC \\
\hline Cmi01 & $\begin{array}{l}\text { F: TTGGGTTAATGTATAGGTACAGATTGG } \\
\text { R: TTTGAACATGCAACTTTGAGC }\end{array}$ & $(\mathrm{ATCT})_{\mathrm{n}}$ & $124-228$ & 0.928 \\
\hline Cmi02 & $\begin{array}{l}\text { F: ATAGCACCCACAGCCACTCC } \\
\text { R: AAGGTGGCCTGTTCATCAGC }\end{array}$ & $(\mathrm{ATCT})_{\mathrm{n}}$ & $175-279$ & 0.941 \\
\hline Cmi03 & $\begin{array}{l}\text { F: CCTCATTACATTGTATGCAACAGC } \\
\text { R: ATTTGGAGACCTCGTGGTGG }\end{array}$ & $(\mathrm{CAT})_{\mathrm{n}}$ & $290-305$ & 0.679 \\
\hline Cmi05 & $\begin{array}{l}\text { F: CATCCTGCACGTTTACACTCC } \\
\text { R: CATTGTTTAAAACCTGGGAGC }\end{array}$ & $(\mathrm{ATCT})_{\mathrm{n}}$ & $242-318$ & 0.895 \\
\hline Cmi07 & $\begin{array}{l}\text { F: CTGTTTGAGTTCTGAGTTTTGGC } \\
\text { R: CGTTTGGCATAATGGTCACG }\end{array}$ & $(\mathrm{ATCT})_{\mathrm{n}}$ & $264-328$ & 0.856 \\
\hline Cmi08 & $\begin{array}{l}\text { F: GAAGGACATCTGGAGGAGAAGG } \\
\text { R: AAGAAAAGGCACGCTTGTGG }\end{array}$ & $(\mathrm{AATAG})_{\mathrm{n}}$ & $226-306$ & 0.722 \\
\hline Cmi09 & $\begin{array}{l}\text { F: ACAGCGCTGACTGTCCACC } \\
\text { R: TTGTGGATCTGCTCGTGTCC }\end{array}$ & $(\mathrm{AGAGC})_{\mathrm{n}}$ & $90-130$ & 0.664 \\
\hline Cmi11 & $\begin{array}{l}\text { F: TGCTAAGAAGCCCTGAACTGG } \\
\text { R: GAATCGCAGTGAACCACACG }\end{array}$ & $(\mathrm{ATT})_{\mathrm{n}}$ & $213-264$ & 0.872 \\
\hline Cmi12 & $\begin{array}{l}\text { F: GAAAGCTGGATGGATTTGGC } \\
\text { R: ATTAAGCGGGTTTGACGACG }\end{array}$ & $(\mathrm{ATT})_{\mathrm{n}}$ & $205-244$ & 0.766 \\
\hline Cmi16 & $\begin{array}{l}\text { F: CTCTCTGTATTATGCCCGAGTCC } \\
\text { R: GCACCAACACCTTGCTACCC }\end{array}$ & $(\mathrm{ATT})_{\mathrm{n}}$ & $179-215$ & 0.812 \\
\hline Cmi17 & $\begin{array}{l}\text { F: GCCAACTAAGCTAACCAACAAGC } \\
\text { R: GTTGTTGTTCTTCCCTGCCC }\end{array}$ & $(\mathrm{AAAT})_{\mathrm{n}}$ & $224-264$ & 0.734 \\
\hline Cmi31 & $\begin{array}{l}\text { F: ACGTCACTCACTACACCCCG } \\
\text { R: AGCTAGCTCAGCCTGGATGC }\end{array}$ & $(\mathrm{ATT})_{\mathrm{n}}$ & $218-260$ & 0.708 \\
\hline Cmi32 & $\begin{array}{l}\text { F: CAGGGTGTATCCTGCCTTCG } \\
\text { R: GCCGTCCATGAAATCTGGC }\end{array}$ & $(\mathrm{ATT})_{\mathrm{n}}$ & $239-269$ & 0.782 \\
\hline Cmi34 & $\begin{array}{l}\text { F: CCAGAAATTGAGCCTGACCC } \\
\text { R: AACCTGGGGTTTAAATCGGG }\end{array}$ & $(\mathrm{TCGGG})_{\mathrm{n}}$ & $275-350$ & 0.549 \\
\hline Cmi35 & $\begin{array}{l}\text { F: TCAGCAAATCATACGGCTGG } \\
\text { R: CTGGCCATTCTCTGTTGGC }\end{array}$ & $(\mathrm{ATT})_{\mathrm{n}}$ & $296-338$ & 0.769 \\
\hline Cmi36 & $\begin{array}{l}\text { F: CAGACATCATTGTTGGCCCC } \\
\text { R: GTCCAAGCACGAATCCAGC }\end{array}$ & $(\mathrm{ATT})_{\mathrm{n}}$ & $148-175$ & 0.843 \\
\hline Cmi38 & $\begin{array}{l}\text { F: CATCATGCATAAAAGTGCCCC } \\
\text { R: TTGGAGCTTAGATGCCTTGC }\end{array}$ & $(\mathrm{ATCT})_{\mathrm{n}}$ & $180-260$ & 0.912 \\
\hline Cmi39 & $\begin{array}{l}\text { F: GTCTGTTCATGCGCACTTCC } \\
\text { R: AATTAGTGCTCAGGGGTGGG }\end{array}$ & $(\mathrm{TTC})_{\mathrm{n}}$ & $160-244$ & 0.932 \\
\hline Cmi40 & $\begin{array}{l}\text { F: TGTTGAGCATGAATGAGTCGG } \\
\text { R: CCTATGAGCCCTATGAACACTGG }\end{array}$ & $(\mathrm{AGTG})_{\mathrm{n}}$ & $189-313$ & 0.946 \\
\hline Cmi41 & $\begin{array}{l}\text { F: CGGACTATTAAAGTACAGTGTGAAAGG } \\
\text { R: CAGTGATACCCAGTCCACCG }\end{array}$ & $(\mathrm{ATCT})_{\mathrm{n}}$ & $254-334$ & 0.886 \\
\hline Cmi42 & F: GAAGGTAATCTGGGTCAGCAGG & $(\mathrm{AAC})_{\mathrm{n}}$ & $273-306$ & 0.706 \\
\hline
\end{tabular}




\begin{tabular}{|c|c|c|c|c|}
\hline & R: CTTGGTGGAAGACCCTCAGC & & & \\
\hline Cmi44 & $\begin{array}{l}\text { F: GGTTCCTAAATGGTTCTTAGATTTGC } \\
\text { R: TGAGCATCCTGCACATTTCC }\end{array}$ & $(\mathrm{ATAGT})_{\mathrm{n}}$ & $235-300$ & 0.706 \\
\hline Cmi45 & $\begin{array}{l}\text { F: TGATTTGCCAGTGTAATGAGAGG } \\
\text { R: CATGGTTTTAATCTTATAATCAGCCG }\end{array}$ & $(\mathrm{ATT})_{\mathrm{n}}$ & $278-305$ & 0.800 \\
\hline Cmi46 & $\begin{array}{l}\text { F: AAATGGAGCCAACTTAGCCG } \\
\text { R: GCAACTGTATCACCCAAACTACC }\end{array}$ & $(\mathrm{ATT})_{\mathrm{n}}$ & $148-169$ & 0.658 \\
\hline Cmi47 & $\begin{array}{l}\text { F: GGAGTCTAACGGAGGGGAGC } \\
\text { R: CAAGTACCTAATAAAATGGCCGC }\end{array}$ & $(\mathrm{ATT})_{\mathrm{n}}$ & 149-194 & 0.827 \\
\hline Cmi48 & $\begin{array}{l}\text { F: GGATGGGTACAAACGAAGGG } \\
\text { R: TGTGCAGGTGTGGTTTACCG }\end{array}$ & $(\mathrm{ATT})_{\mathrm{n}}$ & $226-256$ & 0.778 \\
\hline Cmi49 & F: GTTGCTCTGTACCACTCACCG & $(\mathrm{ATT})_{\mathrm{n}}$ & $105-132$ & 0.679 \\
\hline
\end{tabular}

2 


\section{Table 2 (on next page)}

Genetic diversity per locus and across 20 loci in C. mivartii from Colombian rivers

$\mathrm{Ra}$, allelic size range; $\mathrm{Na}$, average number of alleles per locus; $\mathrm{Ho}$ and $\mathrm{He}$, observed and expected heterozygosity, respectively; $P$, statistical significance for tests of departure of Hardy-Weinberg equilibrium after Bonferroni correction. 


\begin{tabular}{|c|c|c|c|c|c|c|c|c|c|c|c|c|c|c|c|c|c|c|c|c|c|c|}
\hline Site $(N)$ & & $\begin{array}{l}\text { Cmi } \\
31\end{array}$ & $\begin{array}{l}\text { Cmi } \\
\mathbf{4 0}\end{array}$ & $\begin{array}{l}\text { Cmi } \\
46\end{array}$ & $\begin{array}{l}\text { Cmi } \\
44\end{array}$ & $\begin{array}{l}\text { Cmi } \\
41\end{array}$ & $\begin{array}{l}\text { Cmi } \\
39\end{array}$ & $\begin{array}{l}\text { Cmi } \\
03\end{array}$ & $\begin{array}{l}\text { Cmi } \\
47\end{array}$ & $\begin{array}{l}\text { Cmi } \\
32\end{array}$ & $\begin{array}{l}\text { Cmi } \\
36\end{array}$ & $\begin{array}{l}\text { Cmi } \\
38\end{array}$ & $\begin{array}{l}\text { Cmi } \\
49\end{array}$ & $\begin{array}{l}\text { Cmi } \\
45\end{array}$ & $\begin{array}{l}\text { Cmi } \\
09\end{array}$ & $\begin{array}{l}\text { Cmi } \\
01\end{array}$ & $\begin{array}{l}\text { Cmi } \\
17\end{array}$ & $\begin{array}{l}\text { Cmi } \\
08\end{array}$ & $\begin{array}{l}\text { Cmi } \\
16\end{array}$ & $\begin{array}{l}\text { Cmi } \\
11\end{array}$ & $\begin{array}{l}\text { Cmi } \\
12\end{array}$ & $\begin{array}{l}\text { Acro } \\
\text { ss } \\
\text { loci }\end{array}$ \\
\hline \multirow{10}{*}{$\operatorname{Man}(24)$} & $\mathbf{N}$ & 11.0 & 17.0 & 6.00 & 9.00 & 14.0 & 15.0 & 6.00 & 9.00 & 6.00 & 10.0 & 16.0 & 7.00 & 9.00 & 7.00 & 16.0 & 6.00 & 8.00 & 10.0 & 12.0 & 9.00 & 10.1 \\
\hline & $\mathbf{a}$ & 00 & 00 & 0 & 0 & 00 & 00 & 0 & 0 & 0 & 00 & 00 & 0 & 0 & 0 & 00 & 0 & 0 & 00 & 00 & 0 & 50 \\
\hline & H & 0.75 & 0.79 & 0.58 & 0.66 & 0.91 & 0.95 & 0.75 & 0.91 & 0.66 & 0.91 & 0.62 & 0.83 & 0.87 & 0.79 & 0.91 & 0.66 & 0.66 & 0.87 & 0.58 & 0.70 & 0.77 \\
\hline & o & 0 & 2 & 3 & 7 & 7 & 8 & 0 & 7 & 7 & 7 & 5 & 3 & 5 & 2 & 7 & 7 & 7 & 5 & 3 & 8 & 3 \\
\hline & H & 0.78 & 0.93 & 0.69 & 0.72 & 0.91 & 0.92 & 0.76 & 0.87 & 0.77 & 0.87 & 0.93 & 0.77 & 0.84 & 0.73 & 0.93 & 0.76 & 0.73 & 0.81 & 0.88 & 0.85 & 0.81 \\
\hline & e & 5 & 1 & 9 & 9 & 2 & 6 & 7 & 1 & 8 & 8 & 0 & 1 & 9 & 3 & 6 & 2 & 6 & 3 & 7 & 0 & 0 \\
\hline & $\mathbf{P}$ & 0.65 & 0.00 & 0.55 & 0.41 & 0.49 & 0.87 & 0.60 & 0.17 & 0.15 & 0.72 & 0.00 & 0.71 & 0.67 & 0.79 & 0.72 & 0.42 & 0.47 & 0.39 & 0.00 & 0.17 & 0.00 \\
\hline & $\mathbf{P}$ & 7 & 1 & 8 & 9 & 6 & 3 & 8 & 5 & 5 & 2 & o & 9 & 1 & 1 & 7 & 5 & 0 & 6 & o & 5 & 0 \\
\hline & $\mathbf{F}$ & 0.02 & 0.13 & 0.14 & 0.06 & & & 0.00 & & 0.12 & & 0.31 & & & & 0.00 & 0.10 & 0.07 & & 0.32 & 0.14 & 0.04 \\
\hline & & 5 & 1 & 7 & 6 & $\begin{array}{r}.02 \\
6\end{array}$ & $\begin{array}{r}0.03 \\
6\end{array}$ & 1 & $\begin{array}{r}0.01 \\
4\end{array}$ & 5 & $\begin{array}{r}.00 \\
7\end{array}$ & 4 & $\begin{array}{r}0.10 \\
3\end{array}$ & $\begin{array}{r}0.05 \\
2\end{array}$ & $\begin{array}{r}0.10 \\
3\end{array}$ & 0 & 6 & 5 & $\begin{array}{r}0.09 \\
9\end{array}$ & 8 & 9 & 4 \\
\hline \multirow{10}{*}{$\begin{array}{l}\text { Grande(3 } \\
0)\end{array}$} & $\mathbf{N}$ & 8.00 & 23.0 & 7.00 & 9.00 & 10.0 & 17.0 & 6.00 & 8.00 & 7.00 & 10.0 & 16.0 & 8.00 & 10.0 & 7.00 & 18.0 & 6.00 & 7.00 & 10.0 & 12.0 & 9.00 & 10.4 \\
\hline & $\mathbf{a}$ & 0 & 00 & 0 & 0 & 00 & 00 & 0 & 0 & 0 & 00 & 00 & 0 & 00 & 0 & 00 & 0 & 0 & 00 & 00 & 0 & 00 \\
\hline & $\mathbf{H}$ & 0.73 & 0.86 & 0.73 & 0.73 & 0.70 & 0.93 & 0.56 & 0.80 & 0.80 & 0.76 & 0.83 & 0.46 & 0.73 & 0.76 & 0.90 & 0.76 & 0.70 & 0.83 & 0.66 & 0.73 & 0.75 \\
\hline & o & 3 & 7 & 3 & 3 & 0 & 3 & 7 & 0 & 0 & 7 & 3 & 7 & 3 & 7 & 0 & 7 & 0 & 3 & 7 & 3 & 2 \\
\hline & H & 0.75 & 0.95 & 0.75 & 0.68 & 0.88 & 0.94 & 0.72 & 0.83 & 0.76 & 0.87 & 0.93 & 0.73 & 0.84 & 0.73 & 0.91 & 0.75 & 0.74 & 0.85 & 0.87 & 0.79 & 0.80 \\
\hline & e & 0 & 9 & 1 & 5 & 8 & 6 & 0 & 9 & 8 & 2 & 1 & 6 & 0 & 5 & 4 & 6 & 5 & 9 & 7 & 9 & 5 \\
\hline & $\mathbf{P}$ & 0.73 & 0.00 & 0.47 & 0.55 & 0.29 & 0.79 & 0.05 & 0.74 & 0.74 & 0.22 & 0.08 & 0.00 & 0.24 & 0.35 & 0.25 & 0.55 & 0.86 & 0.31 & 0.02 & 0.47 & 0.00 \\
\hline & $\mathbf{P}$ & 9 & 1 & 9 & 3 & 0 & 8 & 0 & 4 & 4 & 9 & 5 & 1 & 4 & 4 & 5 & 7 & 7 & 6 & 5 & 9 & 0 \\
\hline & $\mathbf{F}$ & 0.00 & 0.08 & 0.00 & & 0.19 & & 0.19 & 0.03 & & 0.10 & 0.09 & 0.35 & 0.11 & & & & 0.04 & 0.01 & 0.22 & 0.06 & 0.06 \\
\hline & $F$ & 5 & 1 & 8 & $\begin{array}{r}0.08 \\
8\end{array}$ & 8 & $\begin{array}{r}0.00 \\
3\end{array}$ & 9 & 0 & $\begin{array}{r}0.05 \\
9\end{array}$ & 6 & 0 & 5 & 2 & $\begin{array}{r}0.06 \\
1\end{array}$ & $\begin{array}{r}0.00 \\
2\end{array}$ & $\begin{array}{r}0.03 \\
1\end{array}$ & 5 & 3 & 7 & 7 & 5 \\
\hline \multirow{10}{*}{$\begin{array}{l}\text { Las } \\
\text { Culebras( } \\
29)\end{array}$} & $\mathbf{N}$ & 8.00 & 21.0 & 6.00 & 10.0 & 13.0 & 23.0 & 6.00 & 10.0 & 8.00 & 9.00 & 14.0 & 8.00 & 10.0 & 5.00 & 19.0 & 8.00 & 9.00 & 10.0 & 12.0 & 9.00 & 10.9 \\
\hline & $\mathbf{a}$ & 0 & 00 & 0 & 00 & 00 & 00 & 0 & 00 & 0 & 0 & 00 & 0 & 00 & 0 & 00 & 0 & 0 & 00 & 00 & 0 & 00 \\
\hline & H & 0.75 & 0.89 & 0.65 & 0.62 & 0.72 & 0.89 & 0.75 & 0.86 & 0.79 & 0.79 & 0.79 & 0.75 & 0.72 & 0.58 & 0.79 & 0.79 & 0.79 & 0.75 & 0.75 & 0.62 & 0.75 \\
\hline & o & 9 & 7 & 5 & 1 & 4 & 7 & 9 & 2 & 3 & 3 & 3 & 9 & 4 & 6 & 3 & 3 & 3 & 9 & 9 & 1 & 7 \\
\hline & H & 0.71 & 0.94 & 0.71 & 0.69 & 0.91 & 0.94 & 0.66 & 0.86 & 0.85 & 0.81 & 0.91 & 0.71 & 0.79 & 0.67 & 0.94 & 0.77 & 0.78 & 0.79 & 0.84 & 0.78 & 0.79 \\
\hline & e & 6 & 7 & 8 & 0 & 5 & 3 & 3 & 2 & 2 & 2 & 8 & 7 & 8 & 3 & 4 & 2 & 6 & 3 & 3 & 3 & 3 \\
\hline & D & 0.66 & 0.02 & 0.20 & 0.12 & 0.16 & 0.06 & 0.83 & 0.82 & 0.71 & 0.09 & 0.05 & 0.58 & 0.07 & 0.16 & 0.02 & 0.00 & 0.61 & 0.27 & 0.02 & 0.37 & 0.00 \\
\hline & $\mathbf{P}$ & 7 & 1 & 0 & 2 & 6 & 6 & 9 & 0 & 3 & 1 & 5 & 2 & 4 & 6 & 4 & 6 & 3 & 7 & 9 & 2 & 0 \\
\hline & $\mathbf{F}$ & & 0.03 & 0.07 & 0.08 & 0.19 & 0.03 & & & 0.05 & 0.00 & 0.12 & & 0.07 & 0.11 & 0.14 & & & 0.02 & 0.08 & 0.19 & 0.04 \\
\hline & $F$ & $\begin{array}{r}0.07 \\
8\end{array}$ & 7 & 2 & 5 & 5 & 2 & $\begin{array}{r}0.16 \\
4\end{array}$ & $\begin{array}{r}0.01 \\
8\end{array}$ & 3 & 6 & 1 & $\begin{array}{r}0.07 \\
7\end{array}$ & 7 & 3 & 5 & & $\begin{array}{r}0.02 \\
7\end{array}$ & 6 & 4 & 4 & 1 \\
\hline \multirow{10}{*}{$\begin{array}{l}\text { La } \\
\text { Raya(19) }\end{array}$} & $\mathbf{N}$ & 10.0 & 18.0 & 6.00 & 7.00 & 10.0 & 18.0 & 5.00 & 9.00 & 6.00 & 8.00 & 14.0 & 7.00 & 9.00 & 5.00 & 16.0 & 8.00 & 6.00 & 10.0 & 10.0 & 11.0 & 9.65 \\
\hline & $\mathbf{a}$ & 00 & 00 & 0 & 0 & 00 & 00 & 0 & 0 & 0 & 0 & 00 & 0 & 0 & 0 & 00 & 0 & 0 & 00 & 00 & 00 & 0 \\
\hline & H & 0.94 & 0.89 & 0.63 & 0.52 & 0.63 & 0.94 & 0.52 & 0.78 & 0.78 & 0.78 & 0.84 & 0.63 & 0.73 & 0.84 & 0.84 & 0.52 & 0.57 & 0.73 & 0.73 & 0.73 & 0.73 \\
\hline & o & 7 & 5 & 2 & 6 & 2 & 7 & 6 & 9 & 9 & 9 & 2 & 2 & 7 & 2 & 2 & 6 & 9 & 7 & 7 & 7 & 4 \\
\hline & H & 0.83 & 0.95 & 0.74 & 0.65 & 0.85 & 0.95 & 0.76 & 0.84 & 0.79 & 0.84 & 0.92 & 0.74 & 0.84 & 0.74 & 0.94 & 0.71 & 0.73 & 0.84 & 0.88 & 0.87 & 0.80 \\
\hline & e & 5 & 2 & 0 & 4 & 9 & 0 & 4 & 9 & 2 & 9 & 9 & 1 & 6 & 1 & 2 & 8 & 3 & 2 & 5 & 1 & 3 \\
\hline & D & 0.86 & 0.51 & 0.39 & 0.18 & 0.02 & 0.52 & 0.05 & 0.31 & 0.83 & 0.89 & 0.13 & 0.12 & 0.56 & 0.04 & 0.14 & 0.04 & 0.06 & 0.41 & 0.16 & 0.30 & 0.00 \\
\hline & $\mathbf{P}$ & 3 & 4 & 1 & 9 & 2 & 9 & 0 & 3 & 2 & 0 & 3 & 1 & 3 & 3 & 2 & 2 & 3 & 7 & 1 & 3 & 0 \\
\hline & $\mathbf{F}$ & 0.16 & 0.03 & 0.12 & 0.17 & 0.24 & & 0.29 & 0.04 & & 0.04 & 0.06 & 0.12 & 0.10 & & 0.08 & 0.24 & 0.18 & 0.10 & 0.14 & 0.13 & 0.08 \\
\hline & $F$ & $\begin{array}{r}0.16 \\
5\end{array}$ & 4 & 3 & 4 & 5 & & 2 & 5 & & 5 & 9 & 5 & 6 & & 2 & 8 & 8 & 1 & 5 & 1 & 9 \\
\hline
\end{tabular}




\begin{tabular}{|c|c|c|c|c|c|c|c|c|c|c|c|c|c|c|c|c|c|c|c|c|c|c|}
\hline \multirow{10}{*}{$\begin{array}{l}\text { Panela(3 } \\
5)\end{array}$} & $\mathbf{N}$ & 9.00 & 21.0 & 7.00 & 9.00 & 10.0 & 18.0 & 4.00 & 11.0 & 8.00 & 9.00 & 17.0 & 9.00 & 9.00 & 6.00 & 21.0 & 7.00 & 8.00 & 9.00 & 14.0 & 10.0 & 10.8 \\
\hline & a & 0 & 00 & 0 & 0 & 00 & 00 & 0 & 00 & 0 & 0 & 00 & 0 & 0 & 0 & 00 & 0 & 0 & 0 & 00 & 00 & 00 \\
\hline & H & 0.77 & 0.91 & 0.54 & 0.74 & 0.65 & 0.88 & 0.65 & 0.85 & 0.88 & 0.88 & 0.80 & 0.57 & 0.80 & 0.65 & 0.82 & 0.71 & 0.80 & 0.85 & 0.77 & 0.71 & 0.76 \\
\hline & o & 1 & 4 & 3 & 3 & 7 & 6 & 7 & 7 & 6 & 6 & 0 & 1 & 0 & 7 & 9 & 4 & 0 & 7 & 1 & 4 & 6 \\
\hline & H & 0.73 & 0.95 & 0.69 & 0.78 & 0.89 & 0.93 & 0.72 & 0.84 & 0.78 & 0.86 & 0.91 & 0.69 & 0.81 & 0.64 & 0.91 & 0.77 & 0.76 & 0.83 & 0.88 & 0.81 & 0.80 \\
\hline & e & 2 & 2 & 1 & 8 & 3 & 2 & 9 & 2 & 5 & 4 & 7 & 7 & 3 & 5 & 8 & 1 & 4 & 5 & 7 & 4 & 2 \\
\hline & $\mathbf{D}$ & 0.41 & 0.84 & 0.07 & 0.71 & 0.00 & 0.23 & 0.44 & 0.87 & 0.72 & 0.58 & 0.01 & 0.01 & 0.60 & 0.24 & 0.02 & 0.29 & 0.92 & 0.29 & 0.25 & 0.07 & 0.00 \\
\hline & $P$ & 6 & 3 & 3 & 8 & 1 & 3 & 6 & 7 & 1 & 6 & 2 & 2 & 5 & 0 & 0 & 2 & 3 & 7 & 6 & 6 & 0 \\
\hline & $\mathbf{F}$ & & 0.02 & 0.20 & 0.04 & 0.25 & 0.03 & 0.08 & - & $01 \bar{c}^{-}$ & $0, \overline{-}$ & 0.11 & 0.16 & 0.00 & & 0.08 & 0.06 & $\overline{-}$ & - & 0.11 & 0.10 & 0.04 \\
\hline & $F$ & $\begin{array}{r}0.00 \\
9\end{array}$ & 5 & 3 & 4 & 3 & 6 & 5 & $\begin{array}{r}0.03 \\
3\end{array}$ & $\begin{array}{r}0.14 \\
5\end{array}$ & $\begin{array}{r}0.04 \\
0\end{array}$ & 5 & 8 & 2 & $\begin{array}{r}0.03 \\
3\end{array}$ & 5 & 1 & $\begin{array}{r}0.06 \\
3\end{array}$ & $\begin{array}{r}0.04 \\
2\end{array}$ & 8 & 9 & 4 \\
\hline \multirow{10}{*}{$\begin{array}{l}\text { Chucurí( } \\
35)\end{array}$} & $\mathbf{N}$ & 8.00 & 21.0 & 7.00 & 10.0 & 16.0 & 17.0 & 6.00 & 10.0 & 7.00 & 9.00 & 15.0 & 9.00 & 9.00 & 6.00 & 19.0 & 6.00 & 7.00 & 10.0 & 14.0 & 12.0 & 10.9 \\
\hline & $\mathbf{a}$ & 0 & 00 & 0 & 00 & 00 & 00 & 0 & 00 & 0 & 0 & 00 & 0 & 0 & 0 & 00 & 0 & 0 & 00 & 00 & 00 & 00 \\
\hline & $\mathbf{H}$ & 0.60 & 0.77 & 0.48 & 0.77 & 0.85 & 0.88 & 0.71 & 0.77 & 0.80 & 0.68 & 0.80 & 0.71 & 0.68 & 0.62 & 0.88 & 0.74 & 0.77 & 0.80 & 0.85 & 0.62 & 0.74 \\
\hline & o & 0 & 1 & 6 & 1 & 7 & 6 & 4 & 1 & 0 & 6 & 0 & 4 & 6 & 9 & 6 & 3 & 1 & 0 & 7 & 9 & 3 \\
\hline & $\mathbf{H}$ & 0.68 & 0.95 & 0.68 & 0.73 & 0.90 & 0.92 & 0.70 & 0.83 & 0.79 & 0.88 & 0.92 & 0.69 & 0.81 & 0.70 & 0.94 & 0.78 & 0.77 & 0.80 & 0.89 & 0.80 & 0.80 \\
\hline & e & 0 & 3 & 8 & 3 & 4 & 6 & 4 & 8 & 8 & 1 & 0 & 3 & 7 & 5 & 4 & 7 & 5 & 7 & 2 & 9 & 1 \\
\hline & D & 0.29 & 0.00 & 0.02 & 0.75 & 0.19 & 0.58 & 0.32 & 0.06 & 0.90 & 0.00 & 0.01 & 0.54 & 0.00 & 0.43 & 0.26 & 0.23 & 0.47 & 0.49 & 0.89 & 0.00 & 0.00 \\
\hline & $\mathbf{P}$ & 3 & 0 & 5 & 0 & 2 & 0 & 3 & 9 & 7 & 5 & 9 & 4 & 0 & 5 & 9 & 3 & 7 & 6 & 1 & 3 & 0 \\
\hline & $\mathbf{F}$ & 0.10 & 0.17 & 0.28 & - & 0.03 & 0.03 & - & 0.06 & - & 0.21 & 0.11 & $0-$ & 0.14 & 0.09 & 0.04 & 0.04 & - & - & 0.02 & 0.21 & 0.07 \\
\hline & $F$ & 4 & 9 & 4 & $\begin{array}{r}0.06 \\
8\end{array}$ & 8 & 0 & $\begin{array}{r}0.02 \\
9\end{array}$ & 6 & $\begin{array}{r}0.01 \\
8\end{array}$ & 1 & 8 & $\begin{array}{r}0.04 \\
5\end{array}$ & 8 & 6 & 8 & 2 & $\begin{array}{r}0.01 \\
0\end{array}$ & $\begin{array}{r}0.00 \\
6\end{array}$ & 5 & 2 & 1 \\
\hline \multirow{10}{*}{$\begin{array}{l}\text { Puerto } \\
\text { Berrío(35 } \\
\text { ) }\end{array}$} & $\mathbf{N}$ & 11.0 & 21.0 & 6.00 & 11.0 & 14.0 & 19.0 & 6.00 & 10.0 & 9.00 & 9.00 & 14.0 & 7.00 & 8.00 & 6.00 & 16.0 & 6.00 & 8.00 & 11.0 & 13.0 & 8.00 & 10.6 \\
\hline & $\mathbf{a}$ & 00 & 00 & 0 & 00 & 00 & 00 & 0 & 00 & 0 & 0 & 00 & 0 & 0 & 0 & 00 & 0 & 0 & 00 & 00 & 0 & 50 \\
\hline & $\mathbf{H}$ & 0.51 & 0.97 & 0.65 & 0.74 & 0.88 & 0.80 & 0.82 & 0.85 & 0.82 & 0.97 & 0.65 & 0.71 & 0.80 & 0.68 & 0.91 & 0.80 & 0.71 & 0.77 & 0.91 & 0.40 & 0.77 \\
\hline & o & 4 & 1 & 7 & 3 & 6 & 0 & 9 & 7 & 9 & 1 & 7 & 4 & 0 & 6 & 4 & 0 & 4 & 1 & 4 & 0 & 1 \\
\hline & H & 0.71 & 0.95 & 0.68 & 0.74 & 0.90 & 0.92 & 0.72 & 0.86 & 0.84 & 0.85 & 0.92 & 0.61 & 0.81 & 0.74 & 0.93 & 0.78 & 0.74 & 0.86 & 0.87 & 0.62 & 0.79 \\
\hline & e & 5 & 2 & 8 & 6 & 7 & 3 & 2 & 3 & 2 & 0 & 1 & 7 & 9 & 8 & 1 & 2 & 0 & 0 & 5 & 8 & 5 \\
\hline & $\mathbf{P}$ & 0.00 & 0.65 & 0.78 & 0.47 & 0.60 & 0.00 & 0.22 & 0.17 & 0.70 & 0.54 & 0.00 & 0.82 & 0.31 & 0.49 & 0.53 & 0.97 & 0.67 & 0.25 & 0.34 & 0.00 & 0.00 \\
\hline & $\mathbf{P}$ & 3 & 2 & 1 & 6 & 4 & 8 & 6 & 2 & 7 & 2 & 3 & 5 & 4 & 9 & 6 & 8 & 9 & 4 & 4 & 1 & 2 \\
\hline & $\mathbf{F}$ & 0.27 & 003 & 0.03 & 001 & 0.01 & 0.12 & 016 & 000 & 0.00 & 015 & 0.27 & 017 & 0.01 & 0.07 & 0.00 & 003 & 0.02 & 0.09 & & 0.35 & 0.03 \\
\hline & $\mathbf{F}$ & 0 & $\begin{array}{r}0.03 \\
6\end{array}$ & 1 & $\begin{array}{r}0.01 \\
1\end{array}$ & 0 & 1 & $\begin{array}{r}0.10 \\
4\end{array}$ & $\begin{array}{r}0.00 \\
8\end{array}$ & 1 & $\begin{array}{r}0.13 \\
9\end{array}$ & 6 & $\begin{array}{r}0.17 \\
5\end{array}$ & 0 & 0 & 4 & $\begin{array}{r}0.03 \\
8\end{array}$ & 1 & 0 & $\begin{array}{r}0.06 \\
0\end{array}$ & 4 & 0 \\
\hline
\end{tabular}




\section{Table 3(on next page)}

Bottleneck test for $C$. mivartii from some sectors of the Colombian rivers Cauca and Magdalena

Expected heterozygosity excess is presented as P-values from the Wilcoxon sign-rank test using the infinite alleles model (IAM), stepwise mutation model (SMM) and two-phase model (TPM). M ratio: mean ratio of the number of alleles compared with the range in allele size. 
3

\begin{tabular}{lcccc}
\hline \multicolumn{1}{c}{ Site } & IAM & SMM & TPM & M ratio \\
\hline Man & $\mathbf{0 . 0 0 0}$ & 0.663 & $\mathbf{0 . 0 3 8}$ & $0.207 \pm 0.078$ \\
Grande & $\mathbf{0 . 0 0 0}$ & 0.869 & $\mathbf{0 . 0 0 5}$ & $0.206 \pm 0.082$ \\
Las Culebras & $\mathbf{0 . 0 0 0}$ & 0.997 & 0.324 & $0.226 \pm 0.074$ \\
La Raya & $\mathbf{0 . 0 0 0}$ & 0.727 & $\mathbf{0 . 0 2 2}$ & $0.194 \pm 0.075$ \\
Panela & $\mathbf{0 . 0 0 0}$ & 0.980 & $\mathbf{0 . 0 4 1}$ & $0.213 \pm 0.069$ \\
Chucurí & $\mathbf{0 . 0 0 0}$ & 0.934 & 0.101 & $0.218 \pm 0.079$ \\
Puerto Berrío & $\mathbf{0 . 0 0 0}$ & 0.774 & 0.131 & $0.214 \pm 0.072$ \\
\hline
\end{tabular}

4

5

6

7

8 


\section{Table 4 (on next page)}

Pairwise Jost's Dest (upper diagonal) and F'ST (below diagonal) among samples of $C$. mivartii from the Colombian Magdalena-Cauca basin

Values were not statistically significant after the Bonferroni correction. 


\begin{tabular}{|c|c|c|c|c|c|c|c|}
\hline & Man & Grande & Las Culebras & La Raya & Panela & Chucurí & Puerto Berrío \\
\hline Man & & -0.005 & 0.022 & -0.001 & 0.008 & -0.007 & 0.010 \\
\hline Grande & 0.010 & & 0.016 & -0.007 & -0.011 & -0.024 & -0.007 \\
\hline Las Culebras & 0.013 & 0.011 & & 0.013 & 0.020 & 0.007 & 0.016 \\
\hline La Raya & 0.013 & 0.011 & 0.013 & & 0.001 & -0.005 & 0.021 \\
\hline Panela & 0.010 & 0.007 & 0.011 & 0.011 & & -0.010 & 0.006 \\
\hline Chucurí & 0.009 & 0.006 & 0.009 & 0.011 & 0.007 & & -0.005 \\
\hline Puerto Berrío & 0.010 & 0.007 & 0.010 & 0.013 & 0.008 & 0.007 & \\
\hline
\end{tabular}

